\title{
Adult spawning and early larval development of the endangered bivalve Pinna nobilis
}

\author{
Sergio Trigos ${ }^{\mathrm{a}, *}$, Nardo Vicente ${ }^{\mathrm{b}, \mathrm{c}}$, Patricia Prado ${ }^{\mathrm{d}}$, Francisco J. Espinós ${ }^{\mathrm{e}}$ \\ a Innovation Network in Aquaculture Industries of the Valencian Community (RILA-CV), Avda. Naranjos s/n. Edificio Colegio Mayor Galileo Galilei, Local 15, 46022, Valencia, Spain \\ b Institut Océanographique Paul Ricard, Ile des Embiez, 83140 Six Fours les Plages, France \\ ${ }^{\mathrm{c}}$ Institut Méditerranéen de la Biodiversité et de l'Ecologie marine et continentale (IMBE), Aix-Marseille Université, Avignon Université, CNRS, IRD, France \\ d IRTA-Aquatic Ecosystems, Ctra. Poble Nou Km 5.5, 43540 Sant Carles de la Ràpita (Tarragona), Spain \\ e ACUMA Research Center (Aquaculture and Environmental R.C), Polytechnic University of Valencia, Camino de Vera s/n, 46022, Valencia, Spain
}

\begin{abstract}
* Corresponding author at: Innovation Network in Aquaculture Industries of the Valencian Community (RIIA-CV), Avda. Naranjos s/n. Edificio Colegio Mayor Galileo Galilei, Local 15, 46022, Valencia, Spain. E-mail address: strigos@riia.es (S. Trigos).
\end{abstract}

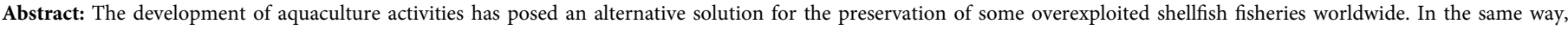

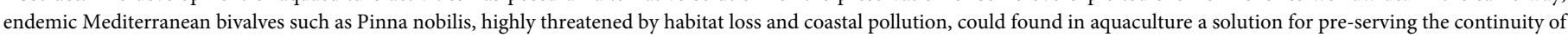

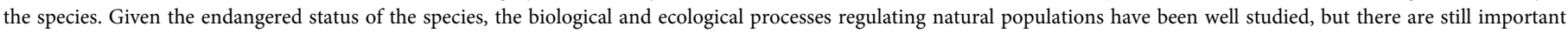

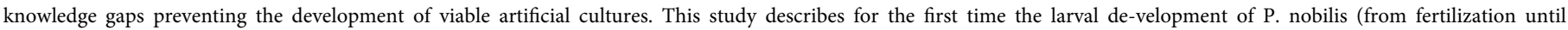

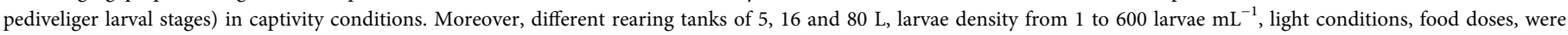

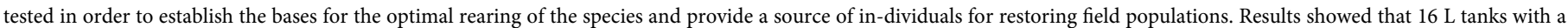

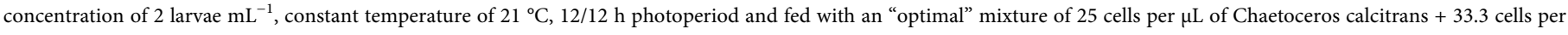

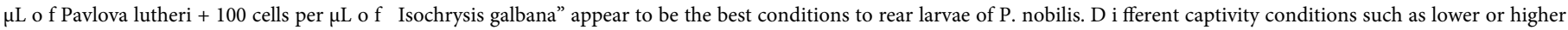
tank volume, larvae density, or food doses; light privation did not report better results for larval development.
\end{abstract}

Keywords: Pinna nobilis, Conservation, Larvae development, Rearing, Captivity

\section{Introduction}

In the last decades the rearing of endangered bivalve species for both commercial and ecological purposes has received considerable attention (Ellis, 2000; Knop, 2009). In spite of the economic and scientific interest, the rearing of bivalve species has been proved to be rather difficult due to the great larval mortalities of the group (Rumrill, 1990). Field studies show that larval mortality in natural conditions ranges from 25 to $80 \%$ during first days of life (Talmage and Gobler, 2009; Gazeau et al., 2010). Both natural and/or anthropogenic-driven mortality in bivalve larvae -i.e.., from egg to postlarval recruit- are often difficult to measure and are considered as a "constant" (Philippart et al., 2003). Possible causes may include failure of fertilization, which is often related to sea acidification and may produce shape abnormal-ities in embryos or avoid development in over $50 \%$ of the larvae (Kurihara et al., 2007); coastal development (Gómez et al., 2000; Guest et al., 2008); shortage of food resources (Rico-Villa et al., 2006), absence of a suitable substrate for benthic settlement ( $\mathrm{Su}$ et al., 2007); combined effects of short planktonic durations and local patterns of marine circulation (Shanks and Brink, 2005); and/or lethal environmental temperatures (Philippart et al., 2003). Any of these scenarios usually leads to a reduction of recruitment rates and consequently, to the disappearance of populations.

Historically, mortality problems have been observed in the marine bivalve industry for decades (Samain and Mccombie, 2008; Barton et al., 2015). The main goal in hatchery production is to improve larval and post-larval survival by achieving larval growth and metamorphosis success. In this term, the proper formulation of larval diets has been considered as the most critical aspect in hatchery operations focusing on the type of microalgae used as feed (Knuckey et al., 2002; Ponis et al., 2006; Rico-Villa et al., 2006; Pettersen et al., 2010; Ragg et al., 2010; Gui et al., 2016) or even in artificial substitutes to phytoplankton 
diet (Coutteau and Sorgeloos, 1992; Knauer and Southgate, 1999; Nevejan et al., 2007; Gui et al., 2016).

In other cases, recurrent mortality episodes are described as a result of virus or Vibrio-like bacteria infecting bivalve hatcheries and nurseries (Renault and Arzul, 2001; Dubert et al., 2015; Rojas et al., 2015) and reducing commercial production by approximately $40 \%$ as reported for French farming facilities of Pacific oyster (Crassostrea gigas) since 2008 (Pernet et al., 2014).

From an ecological perspective, the rearing of endangered bivalves in captivity conditions may pose a potential solution for the rehabilitation of seriously damaged populations (Ronquillo and Mckinley, 2006; Vincie, 2008; Thomas et al., 2010; Theodorou et al., 2015) and face the same early stages' bottlenecks than those reported for bivalve commercial farming (Arnold, 2008). One of these endangered species is the Mediterranean fan mussel, Pinna nobilis. The populations of this bivalve have significantly declined during the last decades (De Gaulejac and Vicente, 1990; Vicente and Moreteau, 1991; Garcia-March, 2005; Basso et al., 2015; Rouanet et al., 2015) as a result of different anthropogenic stressors such as coastal development, fishing pressure, and/or accidental harvesting by trawling and shell breakage by anchoring (Katsanevakis, 2005; Acarli et al., 2011; Hendriks et al., 2011). For these reasons, the European Union included it as an endangered species in the ANNEX IV of the Council Directive 92/43/EEC (EC Habitats Directive), and strictly forbids any kind of culling. Although these measures have helped certain recovery of populations in some Mediterranean regions (Pérez-Vallazza et al., 2008; Theodorou et al., 2017), the species is still at risk by unknown factors such as those causing mass mortality event along the Spanish Mediterranean coast and the Balearic Islands during the summer of 2016 (Darriba, 2017; Vázquez-Luis et al., 2017). Temperature effects due to climate change, coastal pollution, and pathogenic mechanisms are among potential explanatory factors, all of them mediated by human influence (Rodrigues et al., 2015). In this scenario, the rearing of $P$. nobilis in captivity appears as an alter-native solution to obtain healthy stocks of recruits that could be re-introduced in suitable areas with declining population densities (Trigos, 2017). Yet, the duration of the different larval stages from fertilized eggs, as well as the main factors influencing survival rates are still largely unknown, although they are proposed to follow similar patterns to other bivalves. Following this hypothesis, Vicente (1986) described the larval stages of trochophore, veliger, and pediveliger followed by metamorphosis, and juvenile development of $P$ nobilis. De Gaulejac (1989), observed larvae shells with electronic microscope and pointed the possibility of a time gap of 5 to 10 days between gametes expulsion and substrate settlement. Peharda and Vilibić (2008) suggested that veliger fan mussel larvae could have a negative phototactism that allow vertical migration to deeper waters during the day to return to upper bathymetric ranges at night, as also indicated for other bivalves (Gosling, 2003), presumably to avoid UV light or predator activity (Manuel et al., 1996). However, there is still no available information on the behavioural responses of $P$. nobilis larvae to different environ-mental factors under captivity conditions that could provide a solid basis for designing and implementing a viable larval hatchery. In ad-dition, factors determining patterns of benthic recruitment are virtually unknown, although in other species is often linked to the availability of preferential substrates for settlement (Prado et al., 2012), which high-lights the importance of simulating optimal settlement conditions to rear $P$. nobilis in captivity. Other biological and physical aspects such as the possible correlation between adult size and numbers of oocytes expelled also require further investigation.

In this context, the main objective of this work was to describe, for the first time, the larval development of the ecologically important Mediterranean fan mussel ( $P$. nobilis) with the aim of developing cultivation techniques and providing a practical guideline for problem identification during larval rearing in this species. More specifically we conducted experiments aimed (1) at different larval densities (2) with different tank volumes, (3) fed with three doses of microalgae mixture and (4) reared in light/dark conditions.

\section{Materials and methods}

\subsection{Field sampling}

A total of 40 individuals of $P$. nobilis were collected around the Embiez archipelago, South East of France from April 2012 to September 2014. The collected specimens were carefully transported to laboratory facilities within portable tanks and their total height $(\mathrm{Ht})$ registered and labelled. Shells were brushed to remove epibiontic organisms, including other bivalves (Rabaoui et al., 2015) that could affect the fertilization process. All individuals were reintroduced to the field at the end of the experiments.

\subsection{Gamete release and fertilization}

Small groups of 4-6 individuals were placed in two $120 \mathrm{~L}$ tanks within controlled temperature facilities $\left(20-21{ }^{\circ} \mathrm{C}\right)$ with filtered $(1 \mu \mathrm{m})$ and treated (UV) seawater for a maximum of $24 \mathrm{~h}$. $\mathrm{A} \approx 10^{\circ} \mathrm{C}$ gradient is necessary to induce a thermal shock causing gametes release in bi-valves (Helm et al., 2006) which takes place at various temperature thresholds, depending on the species (Drent, 2004). Herein, in order to keep this temperature gradient two induction tanks were prepared; one tank was maintained at $15{ }^{\circ} \mathrm{C}$ while a second tank was heated to $25{ }^{\circ} \mathrm{C}$ thus respecting the conformability range of temperatures described for $P$. nobilis (Trigos et al., 2015).

Individuals were transferred to the induction tanks and individuals were translocated between both of them every $50 \mathrm{~min}$ for a maximum of 6 times. If no response was achieved, individuals were introduced in $2600 \mathrm{~L}$ tanks with constant aeration and water renovation, and the process repeated on the following days. When only males expelled gametes, small volumes of sperm were poured in the tanks on the following thermal shocks, with the aim to stimulate the females (if any) while the thermal shock was occurring. When male and female spawning occurred, individuals were introduced individually in $60 \mathrm{~L}$ tanks in order to avoid possible polyspermia. Both oocytes and spermatozoids were recovered from individual tanks using a sterilized $60 \mathrm{~mL}$ micropipette and then filtered through a $30 \mu \mathrm{m}$ sieve in order to remove any possible fecal waste that could be attached (mainly to oo-cytes). Volumes of $4 \mathrm{~mL}$ of a homogenized sample of oocytes were counted $(N$ $=3$ ) in order to determine the possible correlation between adult size and numbers of oocytes expelled. After that, gametes were introduced together in a $15 \mathrm{~L}$ tank favouring the mixture, thus enhan-cing fertilization.

\subsection{Larval cultures}

Preliminary essays were conducted to determine the optimal rearing conditions according to survival time observed. To this aim and after fertilization, larvae were maintained in the same tank with constant aeration and temperature $\left(21^{\circ} \mathrm{C}\right)$ until they reached the trochophore stage. Then, they were transferred to different small rearing tanks of 5 , 16 and $80 \mathrm{~L}(N=3)$ in order to better control the larvae development and cultures were also adjusted at different larval concentrations of 1, 2 and 600 larvae $\mathrm{mL}^{-1}$ respectively, according to Helm et al. (2006) with water renewal fluxes $\left(600 \mathrm{~mL} \cdot \mathrm{h}^{-1}\right)$ through a $35 \mu \mathrm{m}$ strainer and constant aeration. In addition to exhaustive filtration of seawater circuits periodic, bacterial cultures were carried out to monitor the presence of pathogens within tanks. For each concentration and rearing tank, survival time was estimated daily by sampling $(N=1)$ of $4 \mathrm{~mL}$ and counting of living larvae.

Larvae diet was established using a mixture of three microalgae (Isochrysis galbana, Pavlova lutheri and Chaetoceros calcitrans), as suggested in the literature (Pernet et al., 2005; Milke et al., 2004, 2006). The final concentration mix of the three phytoplankton species was 
adjusted according to three different doses named as "low", "optimal" and "high" using the formula proposed by Helm et al. (2006) for bivalves feeding in breeding facilities:

$V_{\text {dose }}(L)=\frac{\text { cell density needed }[\mu \mathrm{L}] \cdot V_{\text {tank }}}{\text { cell density available }[\mu \mathrm{L}]}$

where:

$V_{\text {dose }}=$ supplied dose in liters.

Cell density needed $[\mu \mathrm{L}]=$ cell concentration according to low, optimal or high dose.

$V_{\text {tank }}(L)=$ tank volume.

Cell density available $[\mu \mathrm{L}]=$ cell concentration in laboratory cultures.

For each concentration mix, the equation included the cell density suggested by the author:"15 Chaetoceros cells per $\mu \mathrm{L}+25$ Pavlova cells per $\mu \mathrm{L}+50$ cells per $\mu \mathrm{L}$ of Isochrysis" for the "low" dose, "25 Chaetoceros cells per $\mu \mathrm{L}+33.3$ Pavlova cells per $\mu \mathrm{L}+100$ cells per $\mu \mathrm{L}$ of Isochrysis" for the "optimal" dose, and "30 Chaetoceros cells per $\mu \mathrm{L}+50$ Pavlova cells per $\mu \mathrm{L}+150$ cells per $\mu \mathrm{L}$ of Isochrysis" for the "high" dose.

\subsection{Effect of rearing conditions on larval development and settlement}

Once previous essays allowed determination of the maximum survival time of larvae under the different parameters established, cultures were also used for testing the influence of light on larvae development due to negative phototactism, as observed for certain bivalve larvae (Raby et al., 1994). To this end, six $16 \mathrm{~L}$ tanks were set with open circulation at densities of 2 larvae $\mathrm{mL}^{-1}$. Three of those tanks were kept at $12 / 12 \mathrm{~h}$ photoperiod whereas the other three tanks were covered with opaque plastic (darkness conditions). Microalgae doses were identically established as "low", "optimal" and "high" to elucidate if the use of any of them could affect directly the larvae growth. The latter was determined by registering larval length with a "Leica DM2500" microscope. A total of 60 fan mussel larvae were daily placed on a dig dish, and their length measured for average estimations ( \pm SD). The process was carried out by triplicate using larvae coming from different spawns.

For all tanks, abiotic parameters were kept as stable as possible. Temperature: $19-21^{\circ} \mathrm{C}$; salinity: $32-37$; $\mathrm{pH}$ : 7.7-8.4; and dissolved oxygen: $5.9-7.0 \mathrm{mg} \mathrm{O}_{2}$. Larvae concentrations were daily monitored ( $N=1$ per tank) to determine the conditions with lower mortality rates. Moreover, an artificial substrate made of $250 \mu \mathrm{m}$ PVC mesh was deployed in all tanks in order to enhance larvae settlement. The substrate was autoclaved $\left(120^{\circ} \mathrm{C} .30 \mathrm{~min}\right)$ to prevent the introduction of pathogens within rearing tanks.

\subsection{Statistical analyses}

All statistical analyses were conducted with SPSS ${ }^{\circledR}$ Statistics 21 program. The possible association between the size of broodstocks and the number of oocytes expelled was studied using the Pearson correlation factor.

The best survival rate was determined studying the effect of the tank volume (fixed factor, three levels) and the larvae density (fixed factor, three levels) and calculated by a two-way factorial ANOVA.

The effect of photoperiod (fixed factor, two levels), food dose (fixed factor, three levels) and rearing day on larvae survival, was investigated using a three-way factorial ANOVA followed by a post-hoc analysis (DHS-Tukey) to establish significant groupings. All data were tested for ANOVA assumptions of normality (Levene's test) and homogeneity of variances (Cochran's test).

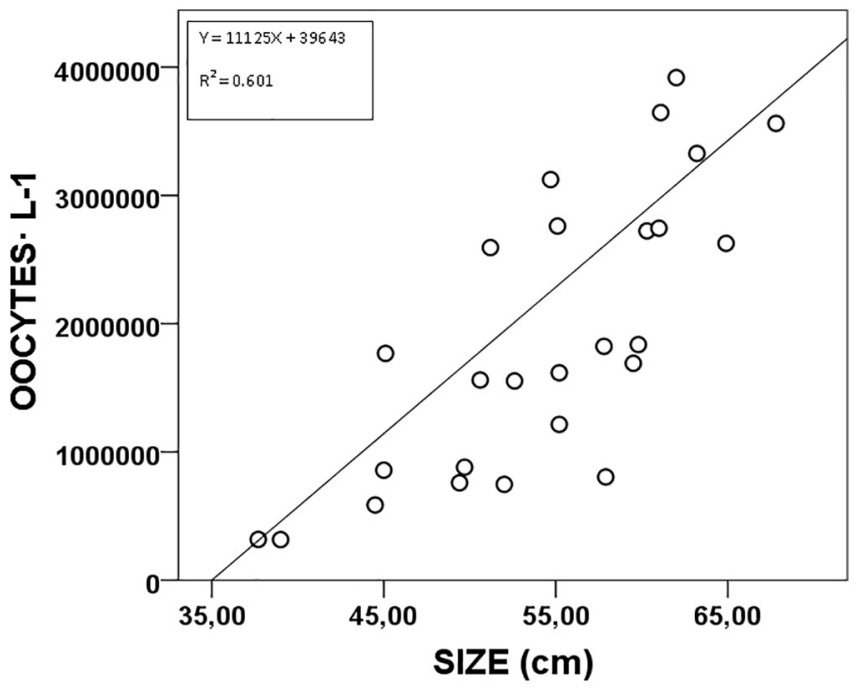

Fig. 1. Correlation between broodstock size $(\mathrm{Ht})$ and number of oocytes expelled per $\mathrm{L}$. $N=26$ adults

\section{Results}

\subsection{Gamete release and fertilization}

A total of 31 individuals $(47.10 \pm 10.61 \mathrm{~cm} \mathrm{Ht})$, of the 40 sub-jected to thermal shock, released gametes for periods of $40 \mathrm{~min}$ and, in some instances for up to $3 \mathrm{~h}$. Among individuals that responded posi-tively, 5 of them $(16.1 \%)$ were strictly males and $14(45.2 \%)$ expelled only oocytes. The remaining 12 specimens (38.7\%) released almost simultaneously male and female gametes. The release of female gametes in $P$. nobilis was estimated in $1.910^{6}$ oocytes $\mathrm{L}^{-1}$ (averaged for the 26 individuals releasing female gametes) with a mean $\mathrm{Ht}$ of $51.8 \pm 9.98$ cm (Fig. 1).

There was a significant a positive association between the size of individuals and the number of expelled oocytes $(F=0.765 . p<0.01)$ as reported for other bivalve species (Helm et al., 2006). The smallest spawning female was $37.7 \mathrm{~cm} \mathrm{Ht}$, and $34.6 \mathrm{~cm} \mathrm{Ht}$ in males. In those instances in which there was only male spawning, sperm was stored in a temperature controlled room at $4{ }^{\circ} \mathrm{C}$ and visual observations revealed that sperm remained alive for a maximum of 3 days.

\subsection{Larval cultures}

Viable oocytes were spherical with an average diameter of $\emptyset=55$ $\pm 1 \mu \mathrm{m}$ whereas spermatocytes hardly exceed $1 \mu \mathrm{m}$ length. Embryonic development of $P$. nobilis started with the rapid fertilization of oocytes by surrounding spermatocytes at a temperature of $21^{\circ} \mathrm{C}$ (Table 2). After 15-30 min the appearance of the first polar body and the formation of a perivitelline membrane confirmed successful ferti-lization (Fig. 2). The first zygote inclusions were observed after $40 \mathrm{~min}$ and gradually increase the number of blastomeres in a successive for-mation of inclusions until they attained a ciliated blastula stage $5 \mathrm{~h}$ later. Herein, the phase in which the motility of larvae begins (Fig. 3) and last for $24 \mathrm{~h}$ until the trocophore stage at an average size of $65 \pm 5 \mu \mathrm{m}$. This was followed by a period of frenetic activity where larvae can reach speeds of 0.5 to $1 \mathrm{~cm} \cdot \mathrm{s}^{-1}$ and displayed a helical swimming pattern as observed in other bivalves (Troost et al., 2008). This speed was considerably reduced after the first $48 \mathrm{~h}$ when the larvae started to generate their own shell (Prodissoconch I) and become a D-larva or early veliger stage (85 $\pm 3 \mu \mathrm{m})$. Here, the appearance of a ciliary structure or "vellum" produced an incessant movement that generates a current of attraction that allows the capture of phyto-plankton cells. Later, the carbonate shell that protects the visceral 
Table 1

Different established doses depending on volume and cell density.

\begin{tabular}{llll}
\hline & Low dose (L) & Optimal dose (L) & High dose (L) \\
\hline Tank 5 L & & & \\
Chaetoceros calcitrans & - & 0.04 & - \\
Isochrysis galbana & - & 0.14 & - \\
Pavlova lutheri & - & 0.05 & - \\
Total (L) & - & 0.23 & - \\
Tank 16 L & & & 0.14 \\
Chaetoceros calcitrans & 0.07 & 0.11 & 0.69 \\
Isochrysis galbana & 0.23 & 0.46 & 0.23 \\
Pavlova lutheri & 0.11 & 0.15 & 1.05 \\
Total (L) & 0.41 & 0.72 & - \\
Tank 80 L & & & - \\
Chaetoceros calcitrans & - & 0.57 & - \\
Isochrysis galbana & - & 2.29 & - \\
Pavlova lutheri & - & 0.76 & \\
Total (L) & - & 3.62 & \\
& & &
\end{tabular}

Table 2

Time of larvae development in Pinna nobilis at $21{ }^{\circ} \mathrm{C} . \mathrm{pH} 8.50 . \mathrm{O}_{2} 6.5 \mathrm{mgO}_{2} \cdot \mathrm{L}^{-1}$ and salinity 38.0 psu.

\begin{tabular}{lll}
\hline Stage & Cumulated time (h:min) & Size $(\mu \mathrm{m})$ \\
\hline Spawning & $0: 00$ & 50 \\
Sperm attachment & $0: 00$ & 50 \\
1st polar body & $0: 15$ & 50 \\
Double membrane & $0: 30$ & 50 \\
1st inclusion & $0: 40$ & 55 \\
Blastule & $5: 00$ & 55 \\
Gastrule & $8: 00$ & 55 \\
Early trocophore & $22: 00$ & 65 \\
Late trocophore & $30: 00$ & 70 \\
Early veliger & $48: 00$ & 85 \\
Late veliger & $72: 00$ & 90 \\
Early umbonade & $144: 00$ & 100 \\
Pediveliger & $168: 00$ & 110 \\
\hline
\end{tabular}

cavity of the larvae and the food become more important, reducing cilia movement to an intermittent rotation. Progressively, the larvae secrete more calcium carbonate causing the thickening of shell layers and the development of the first growth rings (Prodissoconch II). Herein, the characteristic straight hinge that gives name to the " $\mathrm{D}$ " larva tends to bend thus reaching the umbonate phase. From this moment the larvae stopped swimming completely but few developed the foot that allows benthic settlement. (See Table 1.)

From the spawning to pediveliger stage the average growth of larvae was estimated at $8.57 \mu \mathrm{m} \cdot \mathrm{day}^{-1}$. However, at some point of the experiments (day 6 in $80 \mathrm{~L}$ tanks and day 7 in $16 \mathrm{~L}$ tanks) all growth was stopped and no more larval development was observed regardless of the rearing conditions and coinciding with the period when larvae stop swimming (red line) (Fig. 4). Thus, larvae remained alive for a maximum of 22 days and statistical analysis showed that there is a significant difference between survival of larvae and the parameters selected for the rearing activity occurring best survival results in $16 \mathrm{~L}$ tanks with an initial larvae density of 2 larvae $\mathrm{mL}^{-1}(\mathrm{~F}=13.542, p<$ 0.05).

\subsection{Effect of rearing conditions on larval development and settlement}

Results from ANOVA showed higher survival of larvae due to the presence of light in the tanks ( $F=4.597, p<0.05)$ and evidenced important differences according to the dose of food provided ( $\mathrm{F}=3.434, p<0.05)$ while interaction between "Tank + Dose" was not significant $(\mathrm{F}=2.910, p=0.58)$. Post-hoc analysis showed that the "optimal" dose significantly improved $(p<0.05)$ larval survival compared to "low" and "high" doses where $>80 \%$ of larvae had died after $48 \mathrm{~h}$ and $96 \mathrm{~h}$, respectively.
The relative daily mortality registered in tanks with photoperiod $12 / 12$ showed mean values of $54.2 \%$ when the dose was "low", $18.3 \%$ when the dose was "optimal" and $34.4 \%$ when the dose was "high". I n addition, the highest values of mortality were also recorded during mainly the first three days, during the trochophore and veliger phases (Fig. 5).

\subsection{Pathologies observed}

In most cases typical symptoms of bacterial infection (Fig. 6) are suspected to have caused the observed mortalities over $80 \%$ during the first 2-9 days. Herein, the loss of the larval "vellum" was observed during the veliger phase. Despite larvae continue alive, the absence of the ciliary structure prevents them to feed properly and after some days die. Another disease observed in dead larvae is easily identifiable by the continuous movement of the bacteria around and inside larvae shells referred as "swarming". In some cases, bacterial infection seems to affect larval motility, generating large clusters of larvae referred as "spotting" at the bottom of the tanks due to the secretion of mucous filaments.

\section{Discussion}

This study reports for the first time the successful spawning and larval rearing to pediveliger stage in captivity conditions of the endangered bivalve $P$. nobilis. This is also the first daily graphic documentation of the early development on this species.

Recent episodes of mass mortality occurred in southwestern Mediterranean coasts for $P$. nobilis accentuates the population regression registered in the last decades and consequently points captivity cultures as a potential solution to restore damaged populations. As described in Trigos (2017) the maintenance of large number of adults in captivity conditions for prolonged periods of time is necessary to obtain enough gametes of both sexes in a species in which the absence of external sexual dimorphism difficult the development of a hatchery protocol.

This study shows how 12 specimens (38.7\%) from the total studied, released almost simultaneously male and female gametes, an event so far unknown in this species, which is described as a successive hermaphroditism, as a mechanism to prevent self-fertilization (De Gaulejac et al., 1995a,b). Interestingly, some expelled oocytes were still in a division process, suggesting that internal fertilization may occur as described for other bivalves such as Ostrea edulis (Peteiro et al., 2007). This observation coupled with the fact that oocytes present higher density than seawater and tended to sink after being released to the media could be indicate of internal fertilization as a common mechanism enhancing the survival of larvae, but further research is needed to confirm this hypothesis.

Spawned oocytes stayed at the tank bottom until the ciliated blastula stage ( $5 \mathrm{~h}$ post-spawning) when they became motile and swimming activity was observed. Life stages from late embryos to the veliger phase are considered as planktonic and potentially disperse by currents. Once the pediveliger stage was reached, larvae ceased to be planktonic and searched for a suitable substrate to start benthic development. Our study observed up to 22 days to achieve the pediveliger stage then to acquire the capability to get attached. In this context, the hypothesis proposed by De Gaulejac (1989) with a period between 5 and 10 days to settlement phase, contrast with our longer period which might be affected by captivity conditions. This could indicate that artificial conditions can be improved in order to obtain better results.

The massive mortality rates observed (up to $100 \%$ at day 4 and day 22 , respectively in dark and light cultures), prevented observing more development phases for $P$. nobilis but as indicated by HernándezHernández (2000) and Robles-Mungaray (2004) for other species of Pinnidae, simultaneously to foot development, the progresses of the pediveliger phase $(110 \pm 10 \mu \mathrm{m}$ size $)$ is characterized by a gradual loss of the "vellum" that gives way to the formation of gills. 

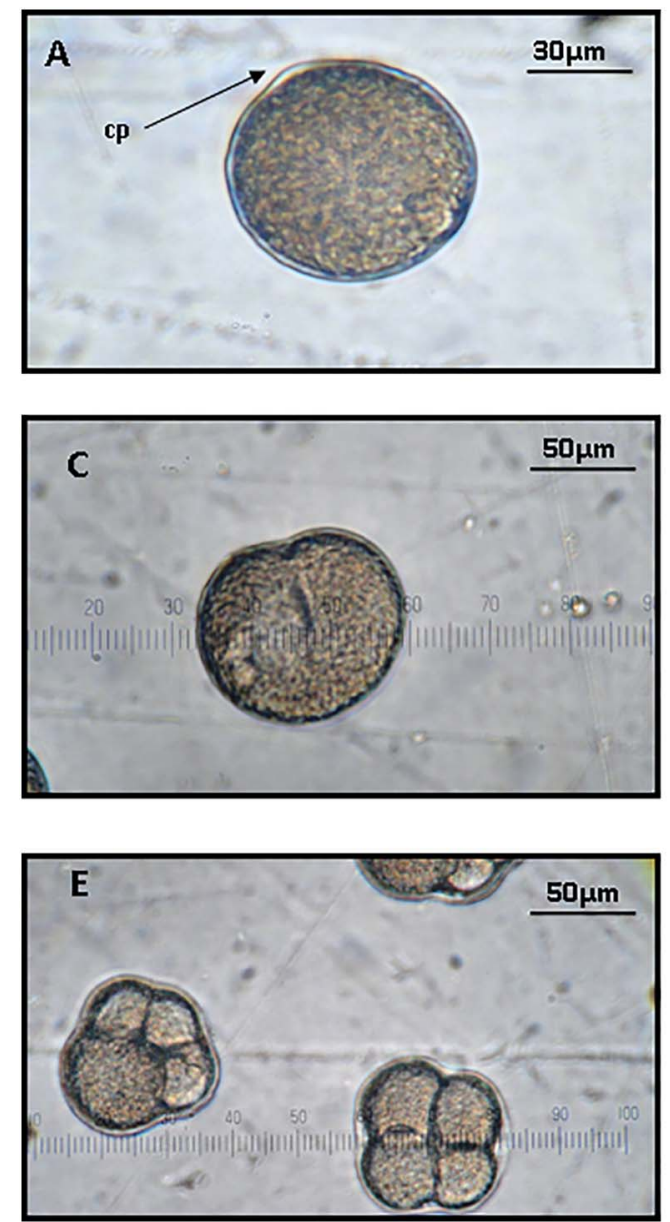
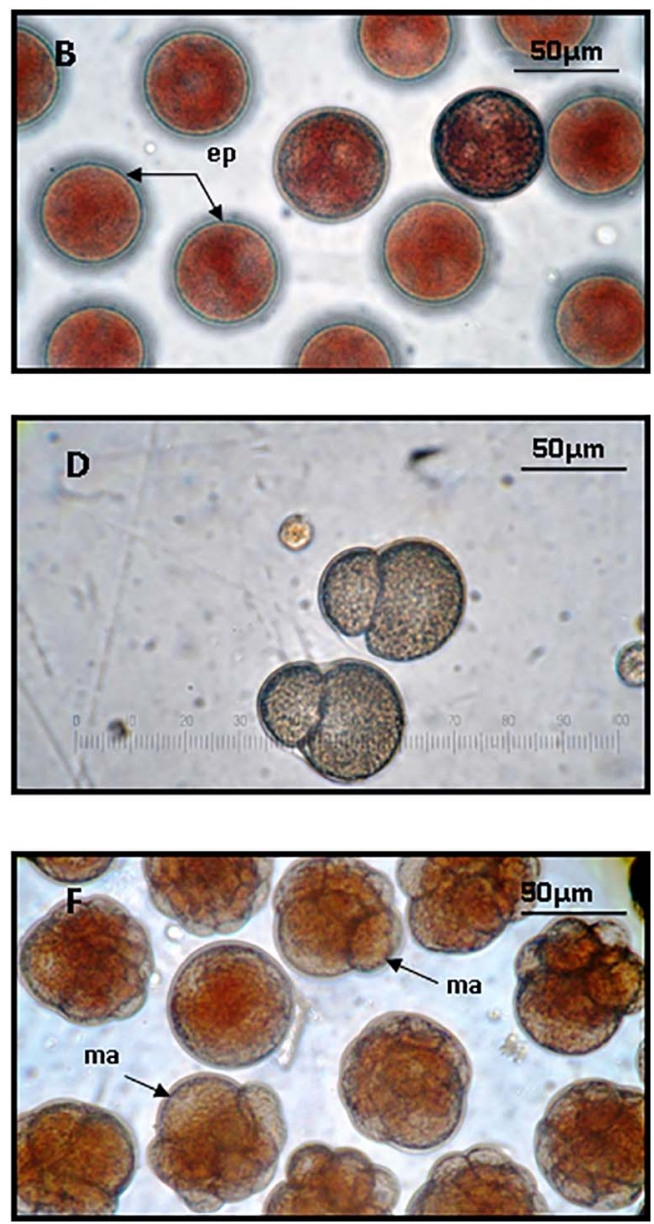

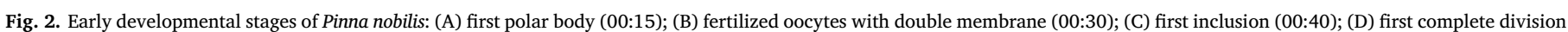
(01:00); (E) 3th and 4th division (03:00); (F) end of cell division phase (04:30). cp. polar body; ep. perivitelline membrane; ma. macromere; mi. micromere.

Subsequently the process of metamorphosis begins with the secretion of new shell from the edge of the Prodissoconch II. Based on the type of growth of other specimens of the same family, the Prodissoconch II should continue its growth in a transverse direction to that previously recorded (Robles-Mungaray, 2004). The appearance of this new structure called dissoconch represents the turning point at which individuals reach the juvenile phase and acquire all adult characteristics such as the typical "pen" shape of the Pinnidae.

In our case, the mortality rates observed at this pediveliger phase were possibly associated to bacterial pathologies which are widespread in hatcheries of commercial species, as well as in regular experimental activities in the laboratory (Andersen et al., 2000; Prado et al., 2016). The infection of larval cultures may be caused by external or horizontal factors such as bacteria escaping the mechanisms of water filtration or other broodstock individuals (Fontanez and Cavanaugh, 2014). The other type of transmission can be vertical when bacterial contamination occurs in gonads and intestinal tracts of broodstock and passes to offspring (Beninger et al., 2003; Prado et al., 2013). These pathologies are thought to mainly affect larvae because they are much more susceptible to bacterial infections than adults (Lambert and Nicolas, 1998). In particular, Vibrio species are regarded as central pathogens in larval bivalve cultures (Gómez-León et al., 2008; Elston et al., 2008; Kesarcodi-Watson. 2009) with new species described in the last years (Prado et al., 2005; Dubert et al., 2015). The most common problem arising from Vibrio action is the necrosis of soft tissues and ciliary structures (Sugumar et al., 1998; Neo et al., 2011), thus preventing filtration and feeding mechanisms that cause the death of the larvae (Dubert et al., 2016). This disease is easily identifiable by the continuous movement of the bacteria around and inside larvae shells referred as "swarming" (Beaz-Hidalgo et al., 2010). The loss of the larval "vellum" during the veliger phase was a typical symptom of bacterial infection. Hence, Vibrio is suspected to have caused the observed mortalities over $80 \%$ during the first $2-9$ days, depending on light conditions and food dose. A low dose of phytoplankton could weaken the larvae being consequently more susceptible to infection. By the contrary, the addition of high doses of the microalgae mixture could be responsible of an excess of non-profited food in the tanks, thus enhancing the proliferation of bacteria. The tanks exposed to the darkness registered mortalities higher than $80 \%$ on the second day and survival tended to improve with the "high" dose. Therefore, the photoperiod is presented as a limiting factor for the development of $P$. nobilis larvae and the high mortality observed could be explained by the absence of light which move the larvae away from natural conditions. This fact is supposed to stress considerably the larvae being consequently more susceptible to infection. According to our results, $P$. nobilis needs light to complete its larvae cycle in contrast with described by Peharda and Vilibić (2008) who suggested that $P$. nobilis veliger larvae have a negative phototactism and migrates vertically to deeper waters during daylight and returns to superficial areas at night, as also indicated for other bivalves (Gosling, 2003).

The loss of vellum tissue also affected larval motility, generating large clusters of larvae referred as "spotting" at the bottom of the tanks due to the secretion of mucous filaments by the larval foot that may measure up to one meter in length (Gérard et al., 1989; Bachelet et al., 1992; Rojas et al., 2009). Further studies need be conducted to determine whether these larvae clusters following the secretion of mucous 

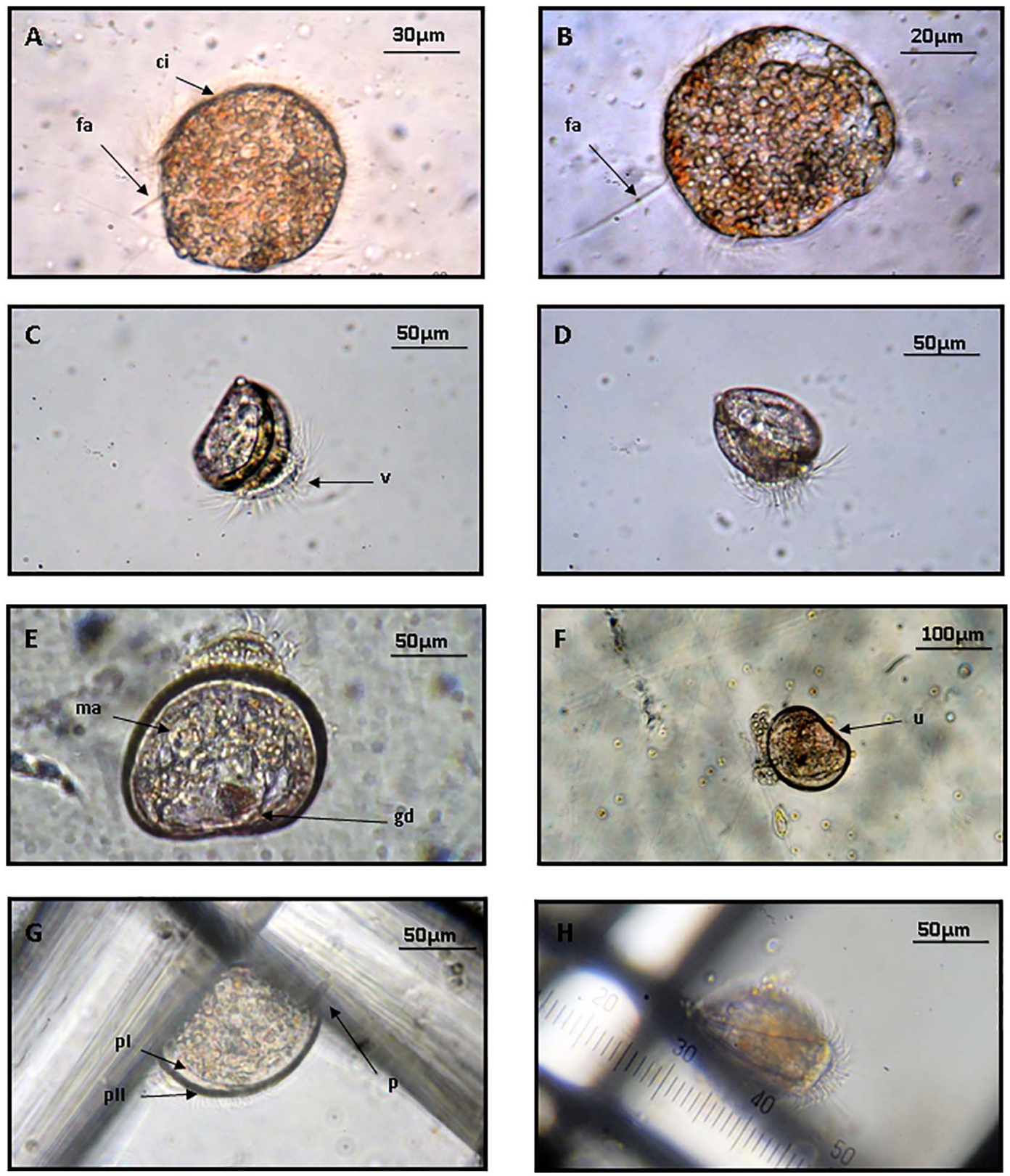

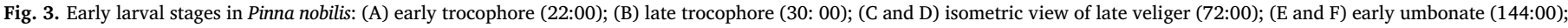

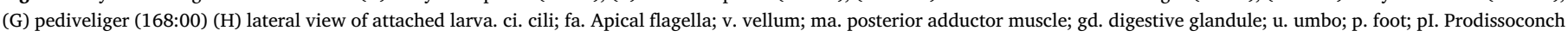
I; pII. Prodissoconch II.

filaments are a side effect of the veil loss or a mechanism to improve larval buoyancy and facilitate dispersal as proposed by Beninger et al. (2003) thus, discerning if it is a natural process or a negative consequence of bacterial activity.

In other Pinnidae such as Atrina maura, success in larvae rearing has not been achieved despite its commercial interest has prompted the study of aquaculture conditions for more than a decade. Coupled with pathologic problems, the larvae of A. maura appear to show a high hydrophobicity which causes the larvae adhesion to the water surface and consequently the death from desiccation and/or starvation (MaedaMartínez, 2008). According to González-Corona (2003) and RoblesMungaray (2004) there are still some biological and technical aspects such as the adjustment of larval density or cleaning protocol, that need be optimized in order to reduce mortality and allow the sustainable commercial production of this bivalve. Therefore, there is a lack of empirical knowledge regarding the mechanisms that trigger disease transmission (Arechavala-Lopez et al., 2013), thus, the optimisation in the hatchery process is accordingly necessary and involves a better understanding of bivalve physiological requirements.

To conclude, this work presents the first detailed information on the biological cycle of Pinna nobilis and provides information concerning important variables determining larval mortality and settlement success, such as light conditions or food dose, establishing the bases for the rearing of the endangered fan mussel $P$. nobilis in captivity. Yet, the closure of its biological cycle in captivity appears to be rather difficult since large mortality rates are observed during first days of life (4 to 22 depending on light treatment). Given that our results are conclusive on the suitability of light conditions and "optimal" food doses, the experimental activity should be intended from a pathological approach, considering bacterial infection as one of the main bottlenecks in the rearing of $P$. nobilis larvae and preventing the development of this species at pediveliger stages. 


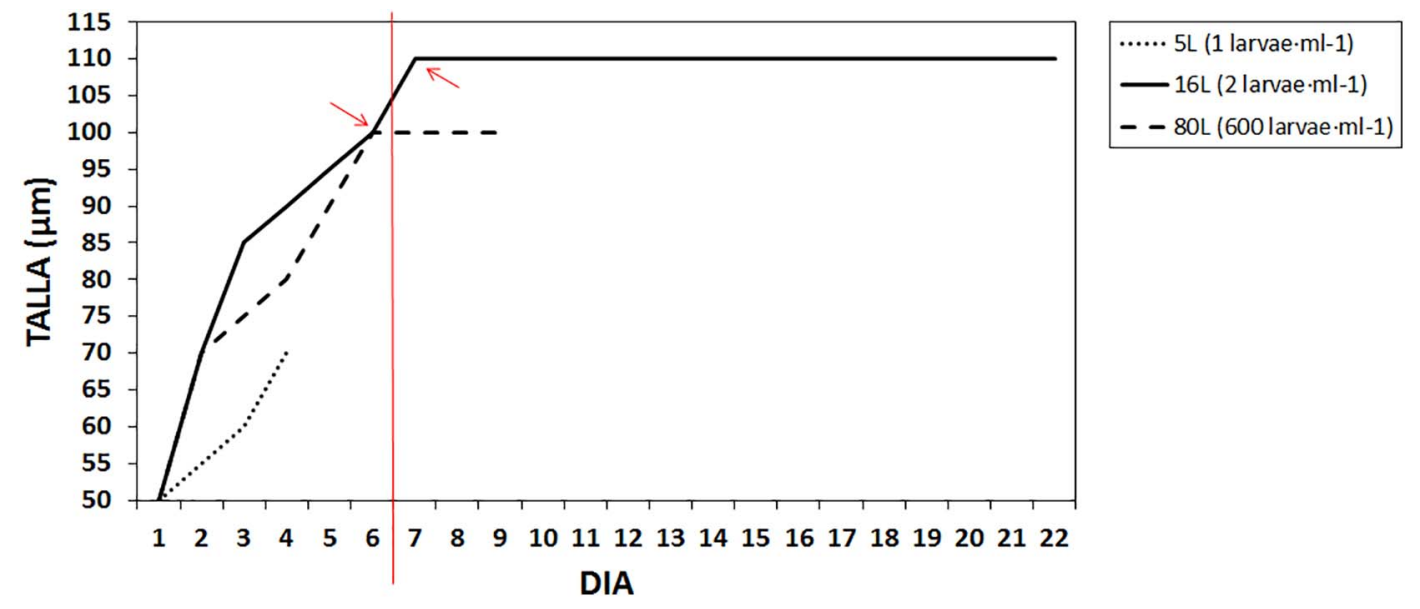

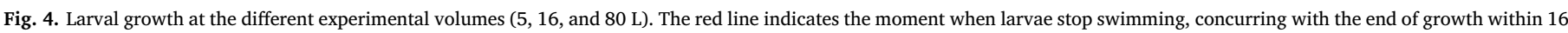
and $80 \mathrm{~L}$ tanks (arrows). (For interpretation of the references to colour in this figure legend, the reader is referred to the web version of this article.)

\section{PHOTOPERIOD 12/12H}

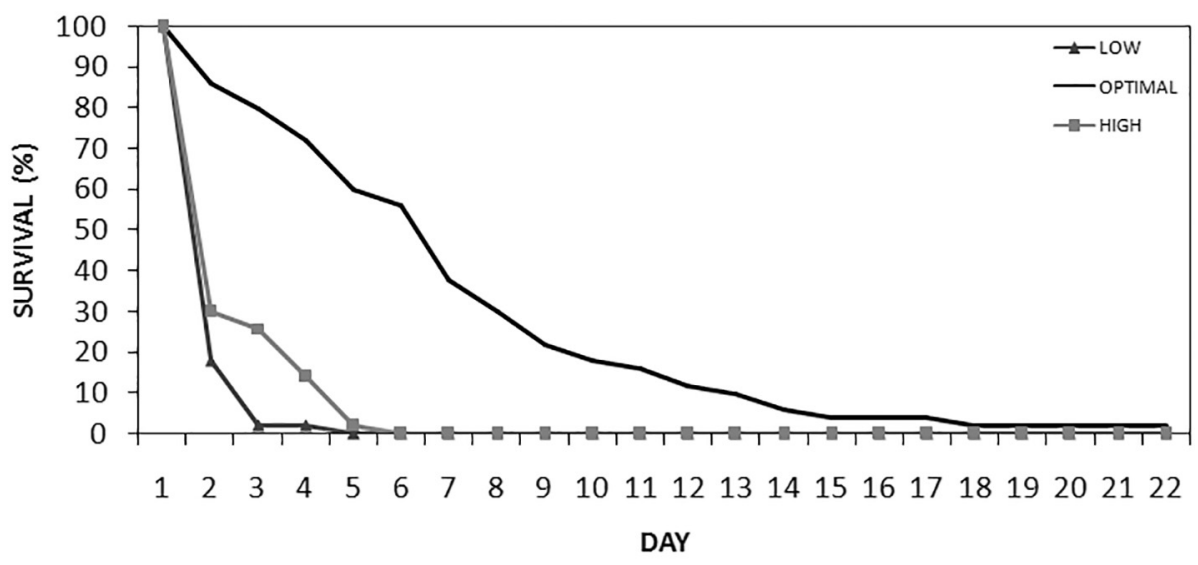

\section{DARKNESS}

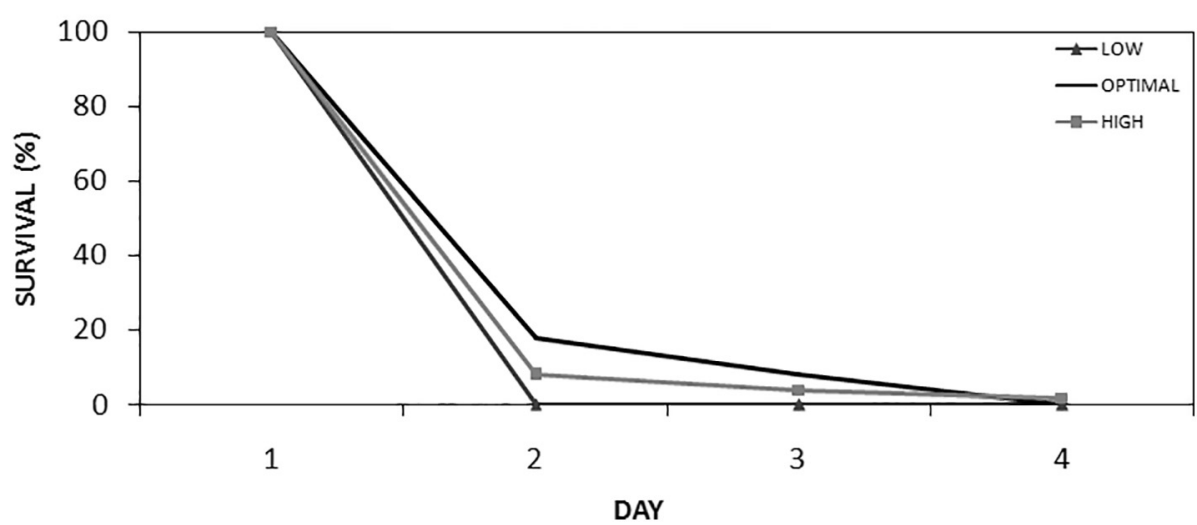

Fig. 5. Daily evolution of larval survival according to photoperiod and phytoplankton dose.

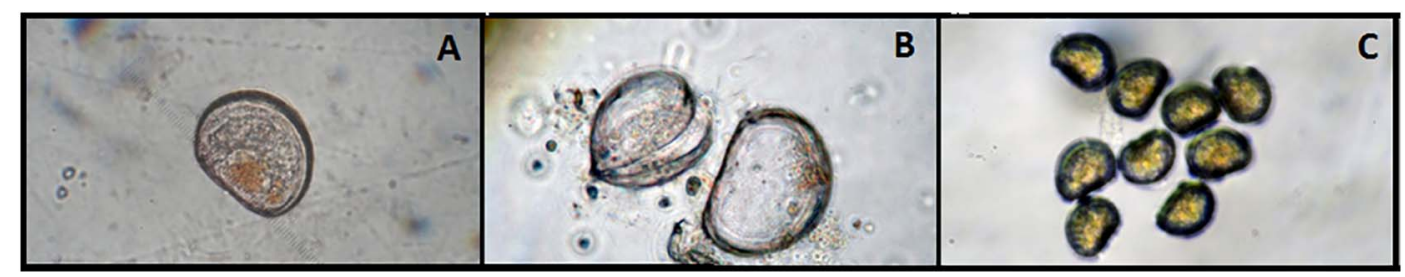

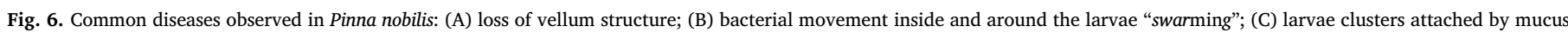
"spotting". 


\section{Acknowledgements}

The present study was financed by the Caisse d'Epargne Côte d'Azur. We are also grateful to the research crew of the Institut Océanographique Paul Ricard and the Catholic University of Valencia for their technical support and help collecting and maintaining fan mussels. Special thanks to the reviewers for their constructive and necessary suggestions.

\section{References}

Acarli, S., Loek, A., Acarli, D., 2011. Preliminary spat settlement of fan mussel Pinna nobilis Linnaeus. 1758 on a mesh bag collector in Karantina island (eastern Aegean Sea. Turkey). Fresenius Environ. Bull. 10, 6.

Andersen, S., Burnell, G., Bergh, Ø., 2000. Flow-through systems for culturing great scallop larvae. Aquac. Int. 8 (2-3), 249-257.

Arechavala-Lopez, P., Sanchez-Jerez, P., Bayle-Sempere, J.T., Uglem, I., Mladineo, I., 2013. Reared fish, farmed escapees and wild fish stocks - a triangle of pathogen transmission of concern to Mediterranean aquaculture management. Aquac. Environ. Interact. 3, 153-161.

Arnold, W.S., 2008. Application of Larval Release for Restocking and Stock Enhancement of Coastal Marine Bivalve Populations. Rev. Fish. Sci. 16 (1-3), 65-71.

Bachelet, G., Guillou, J., Labourg, P.J., 1992. Adult larval and juvenile interactions in the suspension-feeding bivalve. Cerastoderma edule (L.): field observations and experiments. Ann. Inst. Oceanogr. Paris 68, 75-87.

Barton, A., Waldbusser, G.G., Feely, R.A., Weisberg, S.B., Newton, J.A., Hales, B., Cudd, S., Eudeline, B., Langdon, C.J., Jefferds, I., King, T., Suhrbier, A., McLaughlin, K., 2015. Impacts of coastal acidification on the Pacific northwest shellfish industry and adaptation strategies implemented in response. Oceanography 28 (2), 146-159. http://dx.doi.org/10.5670/oceanog.2015.38.

Basso, L., Vázquez-Luis, M., García-march, J.R., Deudero, S., Alvarez, E., Vicente, N., Duarte, C.M., Hendriks, I.E., 2015. The pen shell: a review of population status and recommended research priorities in the Mediterranean Sea. Adv. Mar. Biol. (71), 109-160.

Beaz-Hidalgo, R., Balboa, S., Romalde, J.L., Figueras, M.J., 2010. Diversity and pathogenicity of Vibrio species in cultured bivalve molluscs. Environ. Microbiol. Rep. 2 (1), 34-43.

Beninger, P.G., Le Pennec, G., Le Pennec, M., 2003. Demonstration of nutrient pathway from the digestive system to oocytes in the gonad intestinal loop of the scallop Pecten maximus L. Biol. Bull. 205, 83-92.

Coutteau, P., Sorgeloos, P., 1992. The use of algal substitutes and the requirement for live algae in the hatchery and nursery rearing of bivalve molluscs: an international survey. J. Shellfish Res. 11, 467-476.

Darriba, S., 2017. First haplosporidan parasite reported infecting a member of the superfamily Pinnoidea (Pinna nobilis) during a mortality event in Alicante (Spain, western Mediterranean). J. Invertebr. Pathol. 148, 14-19. http://dx.doi.org/10. 1016/j.jip.2017.05.006

De Gaulejac, B., 1989. Ecologie de Pinna nobilis (L). Mollusque eulamellibranche en baie de Calvi. Étude de la coquille larvaire. Étude des possibilités de réimplantation de l'espèce. DEA "Environnement Marin". Université d'Aix-Marseille III (220pp).

De Gaulejac, B., Vicente, N., 1990. Ecologie de Pinna nobilis (L.) mollusque bivalve sur les co^tes de Corse. Essais de transplantation et experiences en milieu contrôle'. Haliotis 10,17 .

De Gaulejac, B., Henry, M., Vicente, N., 1995a. An ultraestructural study of the gametogenesis of the marine bivalve Pinna nobilis (Linnaeus 1758) I. Oogenesis. J. Moll. Stud. 61, 375-392.

De Gaulejac, B., Henry, M., Vicente, N., 1995b. An ultraestructural study of the gametogenesis of the marine bivalve Pinna nobilis (Linnaeus 1758) II. Spermatogenesis. J. Moll. Stud. 61, 393-403.

Drent, J., 2004. Life history variation of a marine bivalve (Macoma balthica) in a changing world (PhD thesis). Rijksuniversiteit. Groningen., pp. 95-106.

Dubert, J., Romalde, J.L., Prado, S., Barja, J.L., 2015. Vibrio bivalvicida sp. nov. a novel larval pathogen for bivalve molluscs reared in a hatchery. Syst. Appl. Microbiol. http://dx.doi.org/10.1016/j.syapm.2015.10.006

Dubert, J., Nelson, D.R., Spinard, E.J., Kessner, L., Gomez-chiarri, M., Da Costa, F.D., Prado, S., Barja, J.L., 2016. Following the infection process of Vibriosis in Manila clam (Ruditapes philippinarum) larvae through GFP-tagged pathogenic Vibrio species. J. Invertebr. Pathol. 133, 27-33.

Ellis, S., 2000. Nursery and grow-out techniques for giant clams (Bivalvia: Tridacnidae) Center for Tropical and Subtropical Aquaculture Publication CTSA \#143 (99 p). Elston R., Hasegawa, H., Humphrey, K.L., Polyak, I.K., Häse, C.C., 2008. Re-emergence of Vibrio tubiashii in bivalve shellfish aquaculture: severity, environmental drivers, geographic extent and management. Dis. Aquat. Org. 82, 119-134. Fontanez,

K.M., Cavanaugh, C.M., 2014. Evidence for horizontal transmission from multilocus phylogeny of deep-sea mussel (Mytilidae) symbionts. Environ. Microbiol. 16 (12), 3608-3621.

Garcia-March, J.R., 2005. Aportaciones al conocimiento de la biología de Pinna nobilis Linneo. 1758 (Mollusca Bivalvia) en el litoral mediterráneo ibérico. Universitat de Valencia. Servei de Publicacions, Valencia. http://www.tesisenxarxa.net/TDX/TDX UV/TESIS/AVAILABLE/TDX-0628106-132411//garcia.pdf

Gazeau, F., Gattuso, J.P., Dawber, C., Pronker, A.E., Peene, F., Peene, J., Heip, C.H.R. Middelburg, J.J., 2010. Effect of ocean acidification on the early life stages of the blue mussel Mytilus edulis. Biogeosciences 7, 2051-2060.

Gérard, A., Salaün, M., Tritar, S., 1989. Criteres de compétence des larves à la métamorphose chez Pecten maximus. Haliotis 19, 373-380.

Gómez, E.D., Mingoa-Licuanan, S.S., Roa-Quiaoit, H.A., 2000. The culture of true giant clam Tridacna gigas for conservation in the Philippines. Moll. Res. Asia 159-163.

Gómez-León, J., Villamil, L., Salger, S., Sallum, R., Remacha-Triviño, A., Leavitt, D., Gómez-Chiarri, M., 2008. Survival of eastern oyster Crassostrea Virginica from three lines following experimental challenge with bacterial pathogens. Dis. Aquat. Org. 79, 95-105.

González-Corona, J., 2003. Estudio de la fisiología reproductiva y gametogénesis del callo de hacha Atrina maura (Sowerby. 1835). (Tesis de Maestría. Guaymas. Sonora. México, 74 pp).

Gosling, E., 2003. Bivalve Molluscs: Biology. Ecology and Culture. Fishing News Books, Oxford (443 pp)

Guest, J.R., Todd, P.A., Goh, E., Siva, B.S., Reddy, K.P., 2008. Can giant clam (Tridacna squamosa) populations be restored on Singapore's heavily impacted coral reefs? Aquat. Conserv. Mar. Freshwat. Ecosyst. 18, 570-579.

Gui, Y., Zamora, L., Dunphy, B.J., Jeffs, A.G., 2016. Evaluation of the formulated diet MySpat for feeding hatchery-reared spat of the green-lipped mussel, Perna canaliculus (Gmelin, 1791). Aquac. Res. 2016 (47), 3907-3912. http://dx.doi.org/10.1111/are. 12841.

Helm, M.M., Bourne, N., Lovatelli, A., 2006. Cultivo de bivalvos en criadero. In: Un manual práctico. vol. 471 FAO, Roma. c. e. F. N. R. (184 pp).

Hendriks, I.E., Cabanellas-Reboredo, M., Bouma, T.J., Deudero, S., Duarte, C.M., 2011. Seagrass meadows modify drag forces on the Shell of the fan mussel Pinna nobilis. Estuar. Coasts 34, 60-67.

Hernández-Hernández, O., 2000. Distribución y abundancia de larvas de callo de hacha (Bivalvia: Pinnidae) en el sistema lagunar Corralero-Alotengo (Tesis de Licenciatura en Biología Marina). Universidad del Mar, Puerto Angel Oaxaca México (41 p).

Katsanevakis, S., 2005. Population ecology of the endangered fan mussel Pinna nobilis in a marine lake. Endanger. Species Res. 1, 1-9.

Knauer, J., Southgate, P.C., 1999. A review of the nutritional requirements of bivalve and the development of alternative and artificial diets for bivalve aquaculture. Rev. Fish. Sci. 7, 241-280.

Knop, D., 2009. Riesenmuscheln: Arten und Pflege im Aquarium. Dähne Verlag, Ettlingen (220 pp).

Knuckey, R.M., Brown, M.R., Barrett, S.M., Hallegraeff, G.M., 2002. Isolation of new nanoplanktonic diatom strains and their evaluation as diets for juvenile Pacific oysters (Crassostrea gigas). Aquaculture 211 (1), 253-274.

Kurihara, H., Kato, S., Ishimatsu, A., 2007. Effects of increased seawater pCO2 on early development of the oyster Crassostrea gigas. Aquat. Biol. 1, 91-98.

Lambert, C., Nicolas, J.L., 1998. Specific inhibition of chemiluminescent activity by pathogenic Vibrios in Hemocytes of two marine bivalves: Pecten maximus and Crassostrea gigas. J. Invertebr. Pathol. 71 (1), 53-63.

Maeda-Martínez, A.N., 2008. Estado actual del cultivo de bivalvos en México. En A Lovatelli. A. Farías I. Uriarte (eds). Estado actual del cultivo y manejo de moluscos bivalvos y su proyección futura: factores que afectan su sustentabilidad en América Latina. Taller Técnico Regional de la FAO, 20-24 de agosto de 2007. Puerto Montt, Chile, FAO Actas de Pesca y Acuicultura, No 12. Roma. FAO. pp. 91-100.

Manuel, J.L., Gallager, S.M., Pearce, C.M., Manning, D.A., O'dor, R.K., 1996. Veligers from different populations of sea scallop Placopecten magellanicus have different vertical migration patterns. Mar. Ecol. Prog. Ser. 147-163.

Milke, L.M., Bricelj, V.M., Parrish, C.C., 2004. Growth of postlarval sea scallops, Placopecten magellanicus, on microalgal diets, with emphasis on the nutritional role of lipids and fatty acids. Aquac. Res. 234, 20.

Milke, L.M., Bricelj, V.M., Parrish, C.C., 2006. Comparison of early life history stages of the bay scallop, Argopecten Irradians: effects of microalgal diets on growth and biochemical composition. Aquac. Res. 260, 17.

Neo, M.L., Todd, P.A., Chou, L.M., Teo, S.L.M., 2011. Spawning induction and larval development in the fluted giant clam. Tridacna squamosa (Bivalvia: Tridacnidae). Nat. Sing. 4, 157-161.

Nevejan, N., Davis, J., Little, K., Kiliona, A., 2007. Use of a formulated diet for mussel spat Mytilus galloprovincialis (Lamarck 1819) in a commercial hatchery. J. Shellfish Res. $26,357-363$.

Peharda, M., Vilibić, I., 2008. Modelling the recruitment effect in a small marine protected area: the example of saltwater lakes on the island of Mljet (Adriatic Sea). Acta Adriat. 49, 25-35.

Pérez-Vallazza, C., Álvarez-Vázquez, R., Cardona, L., Pintado, C., Hernández-Brito, J., 2008. Cetacean diversity at the west coast of La Palma Island (Canary Islands). J. Mar. Biol. Assoc. UK 88 (06), 1289-1296.

Pernet, F., Bricelj, V.M., Parrish, C.C., 2005. Effect of varying dietary levels of $\omega 6$ polyunsaturated fatty acids during the early ontogeny of the sea scallop. Placopecten magellanicus. J. Exp. Mar. Biol. Ecol. 327, 18.

Pernet, F., Lagarde, F., Le Gall, P., Roque D'orbcastel, E., 2014. Associations between farming practices and disease mortality of Pacific oyster Crassostrea Gigas in a Mediterranean lagoon. Aquac. Environ. Interact. 5 (2), 99-106.

Peteiro, L.G., Filgueira, R., Ayala, A.M., Fernández-Reiriz, M.J., 2007. Ciclo reproductivo de moluscos bivalvos. (IIM.CSIC. NIPO: 251-07-134-3).

Pettersen, A.K., Turchini, G.M., Jahangard, S., Ingram, B.A., Sherman, C.D., 2010. Effects of different dietary microalgae on survival, growth, settlement and fatty acid composition of blue mussel (Mytilus galloprovincialis) larvae. Aquaculture 309, 115-124.

Philippart, C.J., Van Aken, H.M., Beukema, J.J., Bos, O.G., Cadee, G.C., Dekker, R., 2003. Climate-related changes in recruitment of the bivalve Macoma balthica. Limnol. Oceanogr. 48 (6), 2171-2185

Ponis, E., Probert, I., Véron, B., Mathieu, M., Robert, R., 2006. New microalgae for the Pacific oyster Crassostrea gigas larvae. Aquaculture 253, 618-627. 
Prado, S., Romalde, J.L., Montes, J., Barja, J.L., 2005. Pathogenic bacteria isolated from disease outbreaks in shellfish hatcheries. First description of Vibrio neptunius as an oyster pathogen. Dis. Aquat. Org. 67 (3), 209-215.

Prado, P., Tomas, F., Pinna, S., Farina, S., Roca, G., Ceccherelli, G., Romero, J., Alcoverro, T., 2012. Habitat and scale shape the demographic fate of the keystone sea urchin Paracentrotus lividus in Mediterranean macrophyte communities. PLoS One 7, e35170.

Prado, S., Dubert, J., Da Costa, F., Martínez-Patiño, D., Barja, J.L., 2013. Vibrios i n hatchery cultures of the razor clam. Solen marginatus (Pulteney). J. Fish Dis. 37, 209-217.

Prado, P., Roque, A., Pérez, J., Ibáñez, C., Alcaraz, C., Casals, F., Caiola, N., 2016. Warming and acidification-mediated resilience to bacterial infection determine mortality of early Ostrea edulis life stages. Mar. Ecol. Prog. Ser. 545, 189-202.

Rabaoui, L., Belgacem, W., Ismail, D.B., Mansour, L., Tlig-Zouari, S., 2015. Engineering effect of Pinna nobilis shells on benthic communities. Oceanologia 57 (3), 271-279.

Raby, D., Lagadeuc, Y., Dodson, J.J., Mingelbier, M., 1994. Relationship between feeding and vertical distribution of bivalve larvae in stratified and mixed waters. Mar. Ecol. Prog. Ser. 103, 275-284.

Ragg, N.L.C., King, N., Watts, E., Morrish, J., 2010. Optimising the delivery of the key dietary diatom Chaetoceros calcitrans to intensively cultured GreenshellTM mussel larvae, Perna canaliculus. Aquaculture 306, 270-280.

Renault, T., Arzul, I., 2001. Herpes-like virus infections in hatchery-reared bivalve larvae in Europe: specific viral DNA detection by PCR. J. Fish Dis. 24 (3), 161-168. Rico-

Villa, B., Le Coz, J.R., Mingant, C., Robert, R., 2006. Influence of phytoplankton diet mixtures on microalgae consumption, larval development and settlement of the Pacific oyster Crassostrea gigas (Thunberg). Aquaculture 256 (1), 377-388. Robles-

Mungaray, M., 2004. Desarrollo de la biotecnología para la producción de semilla en laboratorio. diploide y triploide. de callo de hacha Atrina maura (Sowerby. 1835). Universidad Autónoma de Baja California Sur. Baja California Sur. México, pp. 66.

Rodrigues, L.C., van den Bergh, J.C.J.M., Massa, F., Theodorou, J.A., Ziveri, P., Gazeau, F., 2015. Sensitivity of Mediterranean bivalve Mollusc aquaculture to climate change and ocean acidification: results from a producers' survey. J. Shellfish Res. 34 (3), $1161-1176$.

Rojas, R., Miranda, C.D., Amaro, A.M., 2009. Pathogenicity of a highly exopolysaccharide-producing Halomonas strain causing epizootics in larval cultures of the Chilean scallop Argopecten purpuratus (Lamarck. 1819). Microb. Ecol. 57 (1), 129139.

Rojas, R., Miranda, C.D., Romero, J., Asenjo, F., Valderrama, K., Segovia, C., Ugalde, J.A., Santander, J., 2015. Genome sequence of Vibrio VPAP30, isolated from an episode of massive mortality of reared larvae of the scallop Argopecten purpuratus. Genome Announc. 3 (4), e00745-15.

Ronquillo, J.D., Mckinley, R.S., 2006. Developmental stages and potential mariculture for coastal rehabilitation of endangered Pacific angelwing clam, Pholas orientalis. Aquaculture 256 (1), 180-191.

Rouanet, E., Trigos, S., Vicente, N., 2015. From youth to death of old age: the 50-year story of a Pinna nobilis fan mussel population at Port-Cros Island Port-Cros National
Park, Provence, Mediterranean Sea. Sci. Rep. Port-Cros Natl. Park 29, 209-222.

Rumrill, S.S., 1990. Natural mortality of marine invertebrate larvae. Ophelia 21, 163-198.

Samain, J.F., Mccombie, H. (Eds.), 2008. Summer Mortality of Pacific Oyster Crassostrea gigas, the Morest Project. Ifremer/Quæ Éditions, Versailles.

Shanks, A.L., Brink, L., 2005. Upwelling, downwelling, and cross-shelf transport of bivalve larvae: test of a hypothesis. Mar. Ecol. Prog. Ser. 302, 1-12.

Su, Z., Huang, L., Yan, Y., Li, H., 2007. The effect of different substrates on pearl oyster Pinctada martensii (dunker) larvae settlement. Aquaculture 271 (1), 377-383.

Sugumar, G., Nakai, T., Hirata, Y., Matsubara, D., Muroga, K., 1998. Vibrio splendidus biovar II as the causative agent of bacillary necrosis of Japanese oyster Crassostrea gigas larvae. Dis. Aquac. Org. 33 (2), 111-118.

Talmage, S.C., Gobler, C.J., 2009. The effects of elevated carbon dioxide concentrations on the metamorphosis, size, and survival of larval hard clams (Mercenaria mercenaria), bay scallops (Argopecten irradians), and eastern oysters (Crassostrea virginica). Limnol. Oceanogr. 54, 2072-2080.

Theodorou, J.A., James, R., Tzovenis, I., Hellio, C., 2015. The recruitment of the endangered fan mussel (Pinna nobilis, Linnaeus 1758) on the ropes of a Mediterranean mussel long line farm. J. Shellfish Res. 34 (2), 409-414.

Theodorou, J.A., James, R., Tagalis, D., Tzovenis, I., Hellio, C., Katselis, G., 2017. Density and size structure of the endangered bivalve Pinna nobilis, (fan mussel) in the shallow water zone of Maliakos Gulf, Greece. Acta Adriat. 58 (581), 63-76.

Thomas, G.R., Taylor, J., De Leaniz, C.G., 2010. Captive breeding of the endangered freshwater pearl mussel Margaritifera margaritifera. Endanger. Species Res. 12 (1), 1-9.

Trigos, S., 2017. Estudio de la ecofisiología y ensayo de cultivo de la nacra Pinna nobilis Linnaeus, 1758 (Tesis doctoral). Universidad Católica de Valencia, Valencia, España.

Trigos, S., Garcia-March, J.R., Vicente, N., Tena, J., Torres, J., 2015. Respiration rates of the fan mussel Pinna nobilis at different temperatures. J. Molluscan Stud. 81, 217-222. http://dx.doi.org/10.1093/mollus/eyu07r5

Troost, K., Veldhuizen, R., Stamhuis, E.J., Wolff, W.J., 2008. Can bivalve veligers escape feeding currents of adult bivalves? J. Exp. Mar. Biol. Ecol. 358, 185-196.

Vázquez-Luis, M., Álvarez, E., Barrajón, A., García-March, J.R., Grau, A., Hendriks, I.E., Jiménez, S., Kersting, D., Moreno, D., Pérez, M., Ruiz, J.M., Sánchez, J., Villalba, A., Deudero, S., 2017. S.O.S. Pinna nobilis: a mass mortality event in western Mediterranean Sea. Front. Mar. Sci. 4, 220. http://dx.doi.org/10.3389/fmars.2017. 00220.

Vicente, N., 1986. La grande Nacre de Méditerranée. Parc national de Port-Cros. ([plaquette de présentation]. 4 volets)

Vicente, N., Moreteau, V., 1991. Statut de Pinna nobilis L. en Mediterranee (Mollusque Eulamellibranche). In: Boudouresque, C.F., Avon, M., Gravez, V. (Eds.), Les Espèces

Marines à Protéger en Méditerranée. GIS Posidonie, Marseille, pp. 159-168. Vincie, M.E., 2008. Development of a Suitable Diet for Endangered Juvenile Oyster Mussels, Epioblasma capsaeformis (Bivalvia: Unionidae), Reared in a Captive Environment. Doctoral dissertation, Virginia Tech. 